\title{
Michigan Sustainability Case: Struggles over Science: What Is the Role for Science in Community Forestry in Nepal?
}

Rebecca Rutt ${ }^{1}$ and Meghan Wagner ${ }^{2}$

\section{Background}

The Michigan Sustainability Cases (MSC) initiative produces case studies for sustainability education. Housed in the School for Environment and Sustainability at the University of Michigan, MSC builds on the tradition of case-based learning, long used in fields such as business, medicine, and law. By coupling a compelling narrative about a complex sustainability problem with informative multimedia elements and an engaged learning exercise, MSC is reinvigorating the case method, making it more exciting and inclusive. Individual case studies are produced by teams of students, faculty, and practitioners and are published on an open-access learning platform at learngala.com. MSC has been producing and piloting case studies since 2016, covering a wide range of sustainability dilemmas.

\section{Introduction}

This case revolves around the forests, forest users, and forest bureaucracy of Nepal. In Nepal, forests are not only important for the national economy but are also critical to the livelihoods of many rural households, supplying firewood, timber, fodder for animals, and nutrients for cropped fields. The country's Community-Based Forest Management regime, introduced in the 1980s, was expected to contribute to both resource sustainability and rural livelihood improvements by permitting users to manage and exploit the local forests upon which they depend. It appeared to be largely a success, but by the early 2000 s, concerns arose anew about the long-term sustainability and economic viability of local management. The Ministry of Forestry and Soil Conservation responded by incorporating a more scientific rationale and technical obligations into the forest management plans that serve as a precondition to transferring authority to local community groups. The new rules required technical forest assessments to generate data about the resource and thereby form the basis for planning, including exploitation regimes and silviculture activities.
The new requirement was expected to better safeguard and promote sustainable resource use through better data about forests, and the forest assessments were justified by their supposed relevance to daily forest management tasks.

However, the role of such technical approaches in actual community-level management remains unclear. An increasing body of research in Nepal indicates that some scientific forest management plans have been elaborated haphazardly, and that some local communities base their forest management on other sources of knowledge. ${ }^{1-4}$ Research is also shedding light on the practical challenges of this requirement, as well as the multiple risks to people and forests that it brings. ${ }^{5}$ Additional research has highlighted misalignment with the needs and interests of some within local communities. ${ }^{1}$ Consequently, an intense debate has emerged in Nepal over whether scientific forest assessments are necessary and under what conditions - a debate that is also occurring in other countries. ${ }^{6-8}$

'Department of Food and Resource Economics, University of Copenhagen, Denmark.

${ }^{2}$ School for Environment and Sustainability, University of Michigan, Ann Arbor, Michigan.

(C) Rebecca Rutt and Meghan Wagner, 2019; Published by Mary Ann Liebert, Inc. This Open Access article is distributed under the terms of the Creative Commons Attribution Noncommercial License (http://creativecommons. org/licenses/by-nc/4.0/) which permits any noncommercial use, distribution, and reproduction in any medium, provided the original author(s) and the source are credited. 
In this case, the reader follows the deliberations of Dr. Indra Raj Poudel, the fictionalized Joint Secretary of Ministry of Forests and Soil Conservation of Nepal, as he decides how best to advise the Minister on whether to retain, remove, or modify the requirement for scientific forest assessments in community forestry. The case asks readers to rethink assumptions about the appropriate role for science in natural resource management, to take context-specific conditions into account, and to dig into the unintended and unacknowledged outcomes of efforts promoting scientific forest management. Specifically, it introduces learners to the concept of scientific forestry in a Nepalese context.

The narrative presented in the following sections provides background on the history of Nepal's Community Forestry Programme and its regulatory evolution. It also introduces arguments both for and against retaining scientific forest management plans. The full, online version of this case features additional elements. Edgenotes (multimedia features displayed alongside the narrative text) provide jumping-off points for deeper exploration of issues raised in the case, including perspectives from Nepalese forestry practitioners. The podcast details the reasons why a top-down approach to forestry has persisted in Nepal. Finally, the engaged learning exercise challenges students to develop their analytical skills by examining the rationales behind, and the outcomes of, scientific approaches to community resource management in other countries. By using a critical lens, students will become more adept at questioning when and how scientific approaches are applied to sustainability problems.

\section{Case Study Introduction}

It was late in the year. Dr. Indra Raj Poudel, Joint Secretary of Ministry of Forests and Soil Conservation of Nepal (MFSC), released a long sigh before taking a sip from his small cup of strong, sweet milk tea. He glanced around his office, noticing that despite his best efforts, the paperwork continued to pile up. The late afternoon light streamed in through the windows of his third-floor office in central Kathmandu. Poudel wanted to go home in time to join his family for dinner. Tonight his wife would prepare chatamari-a rice flour pancake that was his favorite.

Yet, an urgent matter demanded his attention. It was an issue that brought him back to his youth, growing up in a rural, forest-dependent village in the hills of central Nepal. And it was an issue that had featured throughout his career, from forestry school training in the city of Pokhara, to a forestry $\mathrm{PhD}$ in Denmark, and his rise through the ranks of the Nepalese government forest administration. He knew it wouldn't be resolved that evening. But he couldn't get it off his mind.

Poudel was leading a committee tasked with advising the Forests and Soil Conservation Minister on legislation requiring scientific forest assessments in Nepal's Community Forestry Programme.

Forest assessments were intended to provide a detailed picture of forest resources. As such, they were a critical component of scientific forestry, a management strategy aimed at safeguarding sustainability and optimizing forest resources. Scientific forestry prescribed that forest management must be based on periodic plans based on rigorous assessments of the size of the growing stock (static inventory). Based on this knowledge, and assumptions regarding the growth of the forest in response to management prescriptions, forest management plans could be drawn up to guide the management and harvesting of the forest. The overall objective was to ensure that timber harvests did not exceed regrowth over the long term, thereby ensuring long term sustainability.

Forest assessments thereby provided the foundation-and the scienceupon which to construct forest management plans outlining silviculture (forest management through interventions such as thinning, pruning, etc.) and forest product use. The forestry bureaucracy in Nepal (like in many other countries) saw scientific forest management plans as essential to safeguarding the national interest by protecting critical environmental and production values and by their practical relevance and even necessity in day-to-day forest management. This management approach was based on scientific forest management principles and objectives that had been developed in Germany in the early 19th century, emphasizing the optimization of desired forest products (often, timber). Many national forest bureaucracies and training institutes used these principles to equip foresters with the knowledge they needed to bring the country's forests under national control in the name of scientific forestry.

Forest management plans were a crucial component of the Community Forestry Programme. Community forestry, sometimes called participatory forestry, was based on the principle of ownership, whereby people who owned (or had stable access to) resources would better care for and invest in them. By contrast, people who were denied access to critical resources (and even faced criminal charges if they attempted to use them) might be more likely to grab what they could in a haphazard manner, such as hurriedly chopping 
off live branches for firewood. Such practices risked destroying the resource. Widespread belief in the value of ownership drove decentralization processes around the world over several decades. As a result, powers over resources and governance decisions were handed down to subnational levels, including over the management of natural resources like forests.

Community forestry in Nepal had received substantial attention since its formal initiation in the late 1980s. The government's main objective for its Community Forestry Programme was to achieve the twin goals of forest conservation and poverty reduction, with equal emphasis on both. A huge body of scholarship over the years indicated success not only with respect to forest conservation and regeneration, ${ }^{9}$ but also improved local livelihoods, income generation, public goods such as infrastructure, ${ }^{10,11}$ and even a strengthened local democracy. ${ }^{12}$

Of course, the picture wasn't all rosy. ${ }^{13}$ Research also suggested that the benefits of community forestry tended to land disproportionately on the social and economic elites, ${ }^{10}$ and that such groups also dominated decision making. ${ }^{14}$ This typically meant further excluding those most dependent on the forest: the rural poor and/or socially marginalized. Nevertheless, it was undeniable that community forestry in Nepal had become a global model of success. ${ }^{15}$

However, community forestry in Nepal had also become increasingly complex. Forest conditions were largely improving, and interest blossomed in the increasingly valuable resource. New rules also mushroomed in response to growing interest and use. A particularly contentious issue appeared to be the requirement for community forestry groups to produce scientific forest management plans, based upon scientific forest assessments. Some saw them as a relic of a long history of Western imperialism and completely unsuited to Nepal's context. ${ }^{16,17}$ Others believed they were essential to protecting and maximizing the value of Nepal's forest resources. It was Poudel's task to form a cohesive recommendation regarding whether to retain, remove, or modify the rule requiring the scientific assessments. How valuable and necessary were they? What were their true costs? Did they really contribute to more sustainable forests? He had to find a way to satisfy the diverse needs and ambitions both of forest users and of forest bureaucrats.

\section{Origins of Community Forestry and the Changing Legal Landscape}

Since the late 1970s, Nepal's forest area had decreased by 1.7 percent annually, amounting to over 80,000 hectares lost each year. ${ }^{18}$ Clearly, something had to be done. Until the 1980s, centralized, top-down management was widely believed to be the way to best conserve forests. However, mounting evidence from around the globe showed that blocking people from the forests upon which they depended would only compound the problems. In Nepal, one of the poorest countries in the world, natural resources like forestsrather than manufacturing or service industries-had long provided critical products and services for the majority of households and communities. Moral, practical, and sustainability arguments demanded new approaches to managing local forest resources.

It was recognition of the failure of centralized forestry, and increasing appreciation for the value of the ownership principle (an agenda also pushed by the international donor community), which drove the gov- ernment to introduce the earliest forms of community forestry back in the 1980s. Yet, it wasn't until the Forest Act of 1993 that robust rights to community groups over forest resources, products, and revenues, as well as scientific services from the government, were first set down in legal text.

The Act marked the start of the state's official Community Forestry Programme. Section 25(1) of the Act stated: The District Forest Officer may hand over any part of a national forest to a users' group in the prescribed manner entitling it to develop, conserve, use, and manage such forest and sell and distribute the forest products by independently fixing their prices, according to a [management plan]. ${ }^{19}$

In fact, all forests in Nepal were the property of the state. To manage forests, the country had a Ministry of Forests and Soil Conservation, a Department of Forests (and within that, a Community Forestry Division), and subnational district offices staffed with forest officers. Almost all 75 districts of Nepal had a District Forest Office led by a District Forest Officer (DFO) who managed a staff of forest rangers. And, as Section 25 (1) made evident, it was largely the responsibility of these subnational officers and staff to manage the dayto-day realities of the Community Forestry Programme. Over the course of his own career, Poudel had risen through the ranks. Once a DFO, he was now close to the very top of the Ministry-but he remembered well the challenges of negotiating staffing and financial constraints alongside the expectations of both the Ministry and the community groups.

To convince a DFO to hand over a section of forest, community members had to first organize themselves into a Community Forest User Group 
(CFUG). Group sizes varied widely, as did the size of forest area. But all CFUGs were required to submit forest management plans alongside other management documents (such as a constitution containing rules of membership and income use) to the DFO for approval. CFUG forest management plans outlined silviculture activities and, importantly, established rules and limits for harvesting key forest products such as timber and firewood as well as grasses and other non-timber forest products. This was meant to sustain the resources for future generations.

Sections 41 and 42(1) of the same Act stated: "once formed in the prescribed manner, a CFUG shall be an autonomous and corporate body with perpetual succession." But Poudel knew that "perpetual succession" (in other words, the preservation of a CFUG's claim to a forest) could in fact be interrupted, and legislation in the years to come introduced exactly such a possibility.

The year after the Forest Act was passed, Community Forestry Programme Implementation Guidelines issued by the Ministry of Forest and Soil Conservation stated that forest management plans had to have an expiration date and thus were subject to renewal. A period of five or 10 years was to be established. Like most legislation in most countries across the world, community forestry legislation in Nepal had been subject to various updates and amendments over the years. Important to the matter at hand, this principle of renewal had been perpetuated through subsequent legislative revisions, and was now found in the most recent version of the Guidelines. ${ }^{20}$

The 1995 Forest Regulation next outlined the required contents of the management plans mentioned in the Act of 1993, stipulating: "the District Forest Officer shall have to provide technical and other cooperation required by the concerned Users' Group to prepare a Work Plan [management plan] pursuant to this Rule (Section 28 (3))." ${ }^{21}$ In other words, the staff of the District Forest Offices had to support the CFUGs in elaborating forest management plans. This had resulted in unexpected problems, as Poudel was discovering.

Meanwhile, the number of CFUGs grew quickly during the 1990s, and unsurprisingly, many hoped to generate income from forest product sales. Income from timber, firewood, and non-timber forest products could supply many community needsthings like roads, schools, sanitation facilities, and other infrastructure that the government lacked the resources to broadly supply.

\section{Old Problems and New Restrictions}

By the late 1990s, the Ministry of Forest and Soil Conservation publicly expressed renewed concern for forest resources-the same kind of concern that originally drove the initiation of community forestry in the country. Yet this time, the CFUGs and their local income-generating agendas were identified as posing risks to forests. The Ministry reacted by issuing a ban on green (live) tree felling in community forests in 1999. This decision had a large financial impact, as green timber commanded the highest value because it was less likely to be twisted, broken, or decayed. The ban would be lifted only for CFUGs whose management plans were revised or created on-and this was a critical point-the basis of a scientific forest assessment. $^{22,23}$

Some suggested that increasing CFUG timber posed a threat to the Timber
Corporation of Nepal, which was granted monopoly rights to timber sales from government forests in the late 1990s, and was the actual rationale behind the ban. (In other words, the ban was meant to limit timber supply from the CFUGs, which drove timber prices down and thereby the profits of the Corporation). ${ }^{23}$ Whatever the reason, the new rule had the effect of complicating the process of obtaining or renewing community claims by CFUGs over forest resources.

Subsequently, Forest Inventory Guidelines were issued in 2000 (and later revised $^{24}$ ), providing instructions for detailed assessments (inventories) to subnational government authorities and community groups. Once a scientific forest assessment was complete, it was to be used to prescribe the all-important harvest levels of forest products, as captured in the management plan. Levels were to be respected until the forest assessments were conducted anew.

By 2016, there was much to be proud of. The deforestation rate seemed to have declined in accordance with the spread of community forestry across the country, from 2 percent annually between 1990 and 2000, to 1.39 percent between 2000 and 2005, to 0 percent change from 2005 to $2010 .^{18}$ Nepal's Community Forestry Programme was managing around a quarter of Nepal's forest resources, and CFUGs across the country numbered around 18,000. But this image and the realities of success in some parts of the country seemed to be threatened by the demands for more scientific interventions such as the assessments.

\section{Benefits and Opportunities of Scientific Forest Management}

Despite the overall successes, Nepalese forests, especially in certain parts of the country, were receiving 
renewed attention in relation to potential overexploitation and poor management. Many of the voices pointing out the emerging problems also viewed scientific forest management as the solution. Local media outlets publicized reports by Kathmandu policy makers of distressing rates of deforestation and illegal logging in some districts. The story was alarming: Nepalese forests were being "relentlessly denuded." Scientific forest management was posited to contribute to more "effective governance," for instance by curbing illegal tree felling.

Not only was the pressure on from the media. Scientific approaches were also in favor with donors, who sought advice from international organizations like the United Nations, which had promoted scientific forestry approaches for decades in developing countries. Experts from wealthier countries were trained in certain ways to understand and respond to problems-ways that tended to uphold an overarching belief that market-based economic growth is the path for development and wellbeing. Their methods thus aimed to maximize forest incomes.

Speaking the same language of scientific approaches certainly made countries attractive recipient partners for valuable development projects, including in forestry. Official development assistance had constituted around 5 percent of Nepal's gross national income over the past decade. ${ }^{25}$ Poudel felt the pressure to appease international donors.

Perhaps one of the most compelling arguments in support of scientific approaches to forestry stemmed from predictions of the potential revenue it could help generate. Recent research demonstrated the substantial income and development possibilities of some Nepali community forests. A colleague at the Department of Forest had calculated that the old growth forest in the country's low-lying area of Terai could generate revenue of about (U.S.) \$300 million every year-if managed actively and scientifically. This amount was much greater than the combined benefits collected by the government and received by the communities.

It was also believed that scientific forestry could generate thousands of jobs for youths. This mattered to Nepali people. An increasing number of $\mathrm{Ne}$ palese youth were migrating to the Middle East, often for menial or dangerous jobs. Demand for timber was booming both domestically, thanks to the rise in remittances and the service sector, and from Nepal's colossal neighbors, India and China. One government officer had appealed to their colleagues: "The time has come for the forest technicians to show their technical capability by introducing scientific management in these forests." Meanwhile, the Director General of the Forest Department argued for scientific forest management so Nepal did not spend its "hard-earned remittance money" on foreign timber imports, while "stretches of forests remain idle at home, due to limited progress on scientific forest management." This sentiment was echoed frequently within the Ministry.

\section{Challenges and Constraints of Scientific Forestry}

While calls mounted for the greater uptake of scientific forestry approaches in community forestry in Nepal, four problem areas had also started to emerge from the inclusion of scientific forestry to date.

First, there were clearly problems for resource-dependent communi- ties. Communities that did not abide by the rule to create an up-to-date approved forest management plan informed by a recent scientific forest assessment faced suspension or revocation of their rights to the forest, as they could not harvest and sell their forest products, especially timber. In fact, there was a backlog of over 5,000 management plans across the country awaiting scientific assessments and approval by local forest authorities, in effect interrupting the legally mandated perpetual succession. This was problematic in that many people depended on forest products for all kinds of inputs to their subsistence and livelihood needs. In practice, such rules might be overlooked by authorities, especially in light of the resource constraints faced by the authorities themselves to support the production of the assessments. Yet, this perhaps unnecessary situation in some cases also facilitated corruption. Forest authorities had been known to demand payments to provide services. Some collected bribes to promote certain CFUGs ahead in the list or to conduct assessments in a timely manner.

Additionally, not all communities, and not all forests, were able to produce the higher-intensity forest products promoted in scientific assessments, like timber. Some CFUGs that did not have valuable timber struggled to come up with payments and ended up at the bottom of the list. Not all communities even wanted to engage in intensive timber production. Some communities were invested in other sectors, like tourism; many simply used the forest for subsistence purposes. This made it unclear whether such assessments should be imposed across the board. The nurturing of closed canopy, timber-rich forests would also reduce the availability of many of the 
non-timber forest products that many lower-income rural households depended on for their livelihood. ${ }^{26}$

Second, there were also problems that emerged within resource-dependent communities. The requirement that scientific forest assessments be conducted had contributed to division within communities themselves. This was because those who held the prerequisite knowledge of technical processes-not least literacy and numeracy as well as any familiarity with technological instruments-were more likely to be invited and able to participate in activities and discussions around forest assessments and planning. Literacy and numeracy were associated with basic formal education (which many, especially women, lacked in Nepal, where adult literacy rates hovered at under 60 percent) and generally made a person more confident and visible within a community.

As a result, those with some education might be more likely to be selected to local leadership positions, including within CFUGs. Interacting with state forest officials in turn could provide invaluable opportunities to build social networks, through which new opportunities for social mobility could arise. Poudel himself was a perfect example. Being from a small village, he knew that he had benefitted from his professional forestry education. But, he had also worked to develop critical self-reflection about the assumptions he held as a forestry expert in decisionmaking and participatory settings.

In other words, this requirement, however inadvertently, also constituted an additional mechanism for excluding more vulnerable persons in a community. Because they could not 'speak the same language' of science, they were less likely to be included-irrespective of their actual knowledge of the forest. ${ }^{27}$ But were the scientific forest assessments necessary? Were there ways in which sound approaches could be implemented without excluding people who lacked a more formal education?

Third, there were problems for the forest resources. The quality of a management plan depended on the quality of data informing it. Plans were useless if forest inventories were done haphazardly or too infrequently. Unfortunately, forest inventories were very resource-demanding. Poudel feared-well, actually, he knew-that resource-strained forestry officials faced incentives to take shortcuts. Time pressure, minimal access to supportive technologies, and limited human resources all contributed to poorly conducted forest assessments. Yet, these assessments were used to inform management plans and harvesting prescriptions. If based on a model that was applied incorrectly, the prescriptions might call for over- or under-harvesting. This translated into harm for both forests and people. ${ }^{1}$

What did this mean, then, for the actual forest management that was taking place across the country? Some research indicated that local communities drew on other forms of knowledge to inform their management practices under participatory forestry. These communities considered scientific management plans official prerequisites to gain recognized authority over forests rather than relevant support for practical forest management. In other words, not all communities used the scientific management plans in practice. (In fact, Poudel had visited Tanzania only a few weeks back for a forestry conference, and the same issue had been under deliberation there: the importance of scientifically-informed management plans for community managed forests.) ${ }^{6}$

Some CFUGs in Nepal also had recently illustrated the futility of their scientific management plans for actual forest management. In these cases, the forest conditions appeared sound, yet some groups were not even aware of the details of their plan, while others had significantly reduced annual harvesting limits because they lacked confidence in their plan.

Community members in these groups implemented straightforward visual assessments as a basis for decision making about silviculture and harvesting, and drew from their lifetime of experience to conserve their forest resources.

Fourth, there were problems faced by subnational forest officials. Forest officials and particularly the DFO were tasked with supporting the production of resource-demanding assessments along with their other responsibilities of reviewing and approving management plans and other documents. They were accountable for this to their superiors at the Ministry level, but they also lived with the citizens they were supposed to serve. The requirement to assist CFUGs had created an enormous backlog that was due in large part to the lack of resources at their level, which put them in a tight spot on multiple fronts. It was becoming clear to a growing number of Nepalis that the problems of scientific forestry, and technical forest assessments, were multiple.

\section{Time to Take a Position}

As testament to the thorny nature of the problem, quarrels over the rights provided for in national policy had now persisted over several decades among communities, civil society, 
and subnational and national government. ${ }^{15,28}$ Some of these arguments had emerged from the increasing technical demands placed upon communities, embodied in the requirement to produce scientific assessments. ${ }^{22}$ Others were reactions to the political and economic interests that were served when scientific forestry was pursued across the board. $^{23}$

At a recent international conference on the future of community forestry policy and practice, Poudel was reminded how divisive the issue had become. Following a presentation by an international researcher on emerging issues of inventory-based community forest planning, one of his superiors at the Ministry had finally exclaimed:

I don't see why people are debating the role of scientific forestry for sustainable management. Scientific and sustainable forestry is not the question. The question is, how do we create employment from forests, how do we contribute to national budget from forests? Whether we need scientific forestry is not the issue.

Yet, a representative of the Federation of Community Forestry Users Nepal (FECOFUN), a formal network of Forest User Groups (FUGs) from all over Nepal, also gave important insights from the perspective of civil society:

We are not against the inventory system; it just has to be within the communities' understanding. To decide any kind of sustainable system, we cannot disregard the indigenous practices. Setting those aside would be dangerous. There is much data that should be taken down to the local levelpeople should understand what they have.
The issues raised the question of whether the scientific forest management plans were useful management tools or represented superfluous and burdensome bureaucratic measures in participatory forestry. Were they oppressive vestiges of colonialism, or tools for widespread development and pathways out of poverty?

Clearly, the conflicts were mounting, but should the forest assessments be retained, revised, or removed? What should be done to achieve the objectives of the program, to support forest users, to satisfy forest bureaucrats, and to promote the country's interests at large?

\section{Acknowledgments}

The author(s) thank the entire MSC Initiative team for their incredible support in the elaboration of this case. They also sincerely thank Professor Arun Agrawal, Professor Jens Friis Lund, and Dr. Naya Paudel for constructive comments throughout. They thank the International Forestry Resources and Institutions (IFRI) research network for financial support for one of the authors to attend a Community Forests, Sustainability, and Development Workshop in Nepal in May 2018, where supplemental material for this case was gathered. Finally, the authors express their thanks to all those in Nepal, from the Community Forest User Groups, government, and NGOs, that allowed this case to be realized based upon the $\mathrm{PhD}$ research of one of the authors. Michigan Sustainability Cases is supported by a grant from the Transforming Learning for a Third Century Initiative and the School for Environment and Sustainability at the University of Michigan.

\section{Author Disclosure Statement}

No competing financial interests exist.

\section{References}

1. Rutt R, Chhetri BBK, Pokharel R, et al. The scientific framing of forestry decentralization in Nepal. For Policy Econ 2014;60:50-61.

2. Toft MNJ, Adeyeye Y, and Lund JF. The use and usefulness of inventory-based management planning to forest management: Evidence from community forestry in Nepal. For Policy Econ 2015;60:35-49.

3. Basnyat B, Treue T, Pokharel RK, et al. Legal-sounding bureaucratic recentralisation of community forestry in Nepal. For Policy Econ 2018;91: 5-18.

4. Baral S, Meilby H, Chettri B, et al. Politics of getting the numbers right: Community forest inventory of Nepal. For Policy Econ 2018;91:19-26.

5. Nightingale AJ, and Ojha HR. Rethinking power and authority: Symbolic violence and subjectivity in Nepal's Terai forests. Dev Change 2013;44:29-51.

6. Green, K, and Lund JF. The politics of expertise in participatory forestry: A case from Tanzania. For Policy Econ 2015;60:27-34.

7. Faye P. Choice and power: Resistance to technical domination in Senegal's forest decentralization. For Policy Econ 2015;60:19-26.

8. Hansen CP, and Lund JF. Imagined forestry: The history of the scientific management of Ghana's High Forest Zone. Environ Hist Camb 2017;23: 3-38.

9. Nagendra H, Pareeth S, Sharma $\mathrm{B}$, et al. Forest fragmentation and regrowth in an institutional mosaic of community, government and private ownership in Nepal. Landsc Ecol 2007;23:41-54.

10. Lund JF, Baral K, Bhandari N, et al. Who benefits from taxation of forest products in Nepal's community forests? For Policy Econ 2014;38:119125.

11. Chhetri BB, Lund JF, and Nielsen $\varnothing \mathrm{J}$. The public finance potential of 
community forestry in Nepal. Ecol. Econ. 2012;73:113-121.

12. Pokharel BK, Branney P, Nurse $\mathrm{M}$, et al. Community forestry: Conserving forests, sustaining livelihoods and strengthening democracy. J For Livelihood 2007;6:8-19.

13. Hajjar R, Oldekop J, Cronkleton $\mathrm{P}$, et al. The data not collected on community forestry. Conserv Biol 2016;30:1357-1362.

14. Banjade $M R$, Luintel $H$, and Neupane HR. An action and learning process for social inclusion in community forestry. In Kanel KR, Mathema P, Kandel B, et al. (eds.), Twenty-Five Years of Community Forestry: Proceedings of the Fourth $\mathrm{Na}$ tional Community Forestry Workshop. Government of Nepal, Community Forestry Division, Department of Forest, 2004, pp. 480-488.

15. Sunam PK, Paudel NS, and Paudel G. Community forestry and the threat of recentralization in Nepal: Contesting the bureaucratic hegemony in policy process. Soc Nat Resour 2013;26:1407-1421.

16. Scott JC. Nature and space. In Seeing Like a State: How Certain Schemes to Improve the Human Condition Have Failed. Yale University Press, New Haven, CT, 2008, pp. 11-52.

17. Lund JF. Paradoxes of participation: The logic of professionalization in participatory forestry. For Policy Econ 2015;60:1-6.
18. Food and Agriculture Organization of the United Nations (FAO). Global Forest Resources Assessment 2010. Rep. No. FRA 2010/144, 2010. 19. Government of Nepal (GoN). Forest Act, 1993. Official English Version, 1993. http://extwprlegs1.fao.org/ docs/pdf/nep4527.pdf (last accessed $1 / 15 / 2019)$.

20. Government of Nepal (GoN). Guidelines for Community Forestry Development Programme. Ministry of Forest and Soil Conservation, Department of Forests, Community Forest Division, 2009. http://dof.gov.np/ Forest_act (last accessed 1/15/2019). 21. Government of Nepal (GoN). Forest Regulation, 2051. Official English Version, 1995. http://www.forest action.org/app/webroot/js/tinymce/ editor/plugins/filemanager/files/ Forest_Regulation_1995\%20_2_.pdf (last accessed 1/15/2019).

22. Hull J, Ojha $\mathrm{H}$, and Paudel KP. Taking stock of nature: Participatory biodiversity assessment for policy, planning and practice. In Lawrence A (ed.), Forest Inventory in NepalTechnical Power or Social Empowerment? Cambridge University Press, New York, 2010, pp. 165-184.

23. Ojha H, Khanal DR, Sharma N, et al. Federation of community forest user groups in Nepal: An innovation in democratic forest governance. In Proceedings: International Conference on Poverty Reduction and Forests, Bangkok, Thailand, Sept. 3-7, 2007.
24. Government of Nepal (GoN). Scientific Forest Management Guidelines, 2071. Nepali version. Ministry of Forest and Soil Conservation, Department of Forests, 2014. http://dof. gov.np/Forest_act (last accessed 1/ 15/2019).

25. World Bank. Net ODA received (percent of GNI), 2018. http://data. worldbank.org/indicator/DT.ODA. ODAT.GN.ZS?locations=NP. (last accessed 10/5/2018).

26. Kumar S. Does 'participation' in common pool resource management help the poor? A social cost-benefit analysis of joint forest management in Jharkhand, India. World Dev 2002; 30:763-782.

27. Nightingale AJ. 'The experts taught us all we know': Professionalisation and knowledge in Nepalese community forestry. Antipode 2005; 37:581-604.

28. Ojha HR. Techno-bureaucratic doxa and challenges for deliberative governance: The case of community forestry policy and practice in Nepal. Policy Soc 2006;(2):131-175.

Address correspondence to:

Meghan Wagner, PhD

School for Environment and Sustainability

University of Michigan

440 Church Street

Ann Arbor, MI 48109

E-mail: megwagn@umich.edu 